\title{
Influence of Transaction Costs and Governance in the Marketing of Organic Pineapples from Uganda
}

\author{
N. Kwikiriza ${ }^{1}$, J. Mugisha ${ }^{1}$, K. Karantininis ${ }^{2} \&$ P. Rye Kledal ${ }^{3}$ \\ ${ }^{1}$ College of Agricultural and Environmental Sciences, Makerere University, P. O. Box 7062, Kampala, Uganda \\ ${ }^{2}$ Swedish University of Agricultural Sciences (SLU), Department of Economics, P.O. Box 7013, SE-750 07 \\ Uppsala \\ ${ }^{3}$ Institute of Global food and farming, IGFT.Dk-RyMarksvej 89, 1tv-2900 Hellerup, Denmark \\ Correspondence: N. Kwikiriza, College of Agricultural and Environmental Sciences, Makerere University, P. O. \\ Box 7062, Kampala, Uganda. E-mail: normankwikiriza@gmail.com
}

\author{
Received: December 15, $2017 \quad$ Accepted: February 26, $2018 \quad$ Online Published: May 30, 2018 \\ doi:10.5539/jsd.v11n3p194 \\ URL: https://doi.org/10.5539/jsd.v11n3p194
}

\begin{abstract}
The organic pineapple sub-sector in Uganda has existed for slightly over 10 years. Whereas the sub-sector targets the organic market, slightly more than half of the organic pineapples produced by farmers are sold in this market and the rest is sold to the conventional market. This study aimed at determining the transaction costs that limit the amount of organic pineapples sold by farmers to the organic market. The study also aimed at establishing the relationship between the transaction costs and governance of the transactions between farmers and exporters. Data were collected from 140 organic pineapple farmers and seven organic pineapple export companies. Qualitative methods and econometric methods were used in data analysis. Findings show that there were high asset specificity and uncertainty in organic transactions, which resulted into farmers selling only a proportion of their produce to exporters. Involving farmer in contract formulation, trust, distance to collection centers and high asset specificity increased the proportion of pineapple sold by the farmers while farmers' experience reduced the proportion sold. There were three forms of governances between farmers and organic exporters; the captive, modular and relational governance. The relational governance had the highest transaction costs, and less proportion of organic pineapples were sold in this governance. The study recommends transaction cost reduction strategies such as organizing farmers in cooperatives, trust building and engaging farmers in contract formulation.
\end{abstract}

Keywords: governance, organic pineapples, transaction costs, Uganda

\section{Introduction}

Pineapple is one of the most important tropical fruits in the global organic fruit basket. Its market continues to grow for both the fresh, dried pineapple and pulp (Kilcher et al., 2011). Smallholder farmers in Uganda are taking advantage of the favourable tropical climate, fertile soils and the relative ease to convert to organic farming to exploit this market. In return, they obtain premium prices and use the incomes from the sales to improve on their livelihoods (Agro Eco \& Grolink, 2008). The country also diversifies its foreign revenue sources in the face of increased competition in the global market of Uganda's key exports such as coffee and tea. The value chain of organic pineapples also provides a good case towards the current economic debates about meaningful participation of smallholder farmers in high value chains (Ponte, Kelling, Jespersen \& Kruijssen, 2014); consumer sovereignty in the choice of organic food versus conventional food (Singh et al., 2009); and the debate on the judicial use or non- use of agro-chemicals (IFOAM, 2002).

The organic pineapple sub-sector in Uganda has existed for slightly over 10 years, but limited empirical studies have been done about it. Thus, several gaps and economic questions remain unresolved. For example, most farmers sell less than $50 \%$ of their pineapples to the organic market (Kwikiriza, Mugisha, Kledal, Karantininis \& Namuwooza, 2016), and yet their main motivation to producing organic pineapples is to target the global market that pays premium prices (Agro Eco \& Grolink, 2008). The demand for the organically produced pineapples from Uganda in the export market is estimated to be between 5-10 times higher than the supply (Uganda Investment Authority-UIA, 2008), and as a result, organic pineapple consumers seldom meet their quantity needs 
(Kilcher et al., 2011). The question then is; why are less organic pineapples exported or sold to the targeted organic market, and how can more organic pineapples be sold to the intended organic market? Literature has shown that, apart from direct costs, transaction costs contribute to as high as about $35-45 \%$ of the total costs in value chains (North, 1990). In addition, transaction costs have an influence on the nature of governance that exist between actors (Gereffi, Humphrey \& Sturgeon, 2005). This paper addresses two questions that have not been adequately addressed in literature. What transaction costs exist in exchanges between farmers and exporters of organic pineapples from Uganda? What is the relationship between the transaction costs and the nature of governance in the organic pineapple value chains? The paper tests the hypothesis that organic pineapple farmers under the governance with higher transaction costs sell a smaller proportion of their pineapples to the organic market.

\section{Theoretical Background of the Transaction Cost and Governance Theory}

This study adopted both the transaction cost theory (Williamson, 1975) and the global value chain governance theory (Gereffi, Humphrey \& Sturgeon, 2005) to explain the relationship between transaction costs and the governance of the organic pineapple value chains in Uganda. Gereffi, Humphrey and Sturgeon (2005) explain that there are five forms of governance; market, modular, relational, captive and hierarchy in which any transaction can be coordinated. There is a strong relationship between transaction costs and governance because the three exchange conditions, namely; complexity of information and knowledge required in an exchange, ability to codify and transmit information among actors and the capability in the supply base, the magnitude of which determine governance, are all dependent on the prevailing transaction costs (Gereffi, Humphrey \& Sturgeon, 2005). Currently, there is no consistent analytical tool to measure the mentioned exchange conditions, although some studies, for example, Neish (2008) have used constructs to explain the governance in value chains.

Transaction cost properties, asset specificity and uncertainty have gained prominence in transaction costs studies and have been used as proxies for transaction costs (Gonzalez-Moralejo, Muñoz \& Miquel, 2015). Asset specificity refers to the degree to which an asset that supports a given transaction can be transferred to a different use or a different user, while uncertainty refers to unanticipated changes in circumstances surrounding an exchange. Asset specificity can be in several forms; physical, site, spatial, dedicated and knowledge asset specificity; while uncertainty includes behavioral, environmental and technology uncertainty (Williamson, 2005; Martinez, 2002). The two properties influence actors in a transaction to behave opportunistically or to withhold essential information from the other party in the transaction. In extreme cases of high levels of opportunism, a hold up or transaction breakdown occurs (Masten \& Soussier, 2002). Therefore, measurement of asset specificity and uncertainty is important in understanding underlying causes of transaction costs in a transaction. Continuous measures have been used in several studies as proxies for transaction costs. The commonly used measures are distance to market, cost of resources used to locate a trading partner (Benham \& Benham, 2001) and the search or information costs of locating a buyer (Solino \& Gago de Santos, 2010). These proxies, however, fail to give a detailed explanation of the actual transaction costs incurred during a transaction (Macher \& Richman, 2008). Qualitative analysis of the transaction properties provides a richer description and perspective of transaction costs than what most statistical analyses can offer (Masten \& Soussier, 2000).

The global value chain governance assesses the transactions between any two actors (Gibbon \& Bolwing, 2007), and it considers the institutional environment as the background in which the governances operate (Ponte, Kelling, Jespersen \& Kruijssen, 2014). The discussion in this study is limited to exchanges between the organic pineapple exporter and the farmer. In global value chains, the governance of the chain is a result of the strategy and decision making of one actor (Gibbon \& Ponte, 2008). In the case of Uganda organic pineapple value chain, the exporters make the decision on the seemingly most efficient way to trade with the farmers. They recruit the farmers and once the farmers enter into contract with them, their decision on the amount of the pineapple they sell to the exporter will depend, among other factors, the prevailing transaction costs.

This study builds on the transaction cost and governance theory to determine under which form of governance farmers export less proportion of their pineapples, and how this is associated with transaction costs. Application of transaction cost and governance theory in organic value chains is a special case because the organic value chains are short, with minimal involvement of brokers (Kwikiriza, Mugisha, Kledal, Karantininis \& Namuwooza, 2016). The strict certification rules and regulations provide unique characteristics, that are different from other value chains where the theories have been empirically tested. This study also contributes to the on-going buildup of the two theories because; one, the transaction cost and the governance theory have been applied widely on non-agricultural products (Macher \& Richman, 2008), and more scarcely on organic products; two, it provides evidence on existence of multiple governances in a single value chain; and three, it contributes to the growing 
literature on the relevance of the use of qualitative measures in estimating transaction costs.

\section{Methodology}

\subsection{Description of the Study Area}

The study was done in five districts in Uganda; Luwero, Kayunga, Wakiso, Mubende and Iganga in 2014. They were purposively selected because organic pineapple exporters bought the pineapples only from these areas. The districts are situated in the Lake Victoria crescent, where temperatures are moderate, less humid with plentiful of rain and fertile soils that favor fruit production. The study area is also near Kampala city, which makes transportation of the produce and coordination of the activities between the farmers and exporters easier.

\subsection{Study Design, Sampling Procedure and Data Collection}

The study targeted the farmers who were actively selling to the organic exporters. Probability proportionate to size sampling (Bar-Hillel, 1979) was used to select 140 farmers from 450 certified organic pineapple farmers. The 450 farmers subscribed to seven organic export companies that were actively exporting pineapples. Top managers of these companies were interviewed. A structured questionnaire, with some open-ended questions was used to obtain data from both the farmers and the exporters. Four focus group discussions were held with the farmers (8-12 farmers in each group) to supplement the quantitative data that was obtained using the structured questionnaire. The data collected from farmers included their age, education levels, their experience in organic pineapple farming, markets of organic pineapples, their interaction with exporters during the transactions, and transaction cost specific information.

\subsection{Data Analysis}

\subsubsection{Determining Transaction Costs Experienced by Farmers and Exporters}

Two approaches were used to determine the transaction costs between the farmers and exporters. In the first approach, qualitative methods, were used to explain the transaction costs. In this approach, farmers and exporters were encouraged to narrate all the constraints they faced. These were recorded by the enumerators, and during analysis were categorized as either transaction cost related or non-transaction cost related constraints. The transaction costs were summarized by counting the number of times (frequencies) a transaction cost was mentioned, and were grouped as either asset specificity or uncertainty transaction cost properties. The second approach involved farmers only. They gave a score on several transaction cost proxies that were applicable to them, rated on a 3 likert scale measure.

3.3.2 Estimating the Relationship between transaction costs, governance choice and proportion of Pineapples Sold to Organic Exporters

In the organic pineapple value chains in Uganda, farmers incur transaction costs which may differ depending on the prevailing governance between the exporter and the farmer. A one way sidak test was used to assess the magnitude of the transaction costs incurred in the different forms of governance. To test the hypothesis that a smaller proportion of organic pineapples are sold by the farmers in the governance with high transaction costs, a Generalized Linear Model (GLM) of the Gaussian family with an identity link (Papke \& Wooldridge, 1996) was used. This model was chosen because the dependent variable (proportion of organic pineapple sold by the farmer) is a continuous variable whose distribution does not satisfy the normality assumptions. The model was tested against other possible models using the link test, BIC and the AIC, which all showed that the model gives the best specification of the relationship. It was specified as in equation (1) and estimated as in equation (2). Table 1 shows transaction cost, production and demographic variables used in the model.

$$
\text { sales }=\alpha+\beta X_{i}+\mu_{i}
$$

Where $X_{i}$ are the independent variables used to explain the variation in the proportion sold

$$
\begin{gathered}
\text { sales }=\alpha+\beta_{1} \text { gov }+\beta_{2} \text { trust }+\beta_{3} \text { cont }+\beta_{4} \text { dist }+\beta_{5} \text { capt }+\beta_{6} \text { effort }+\beta_{7} \text { write }+\beta_{8} \text { buy }+\beta_{9} \text { pay }+ \\
\beta_{10} \text { land }+\beta_{11} \text { exp }++\beta_{12} \text { train }+\beta_{13} \text { age }+\beta_{14} \text { educ }+\beta_{15} \text { sex }+\mu
\end{gathered}
$$

$\beta_{1-} \beta_{15}$ are the coefficients on the variables affecting the proportions sold, and $\mu$ is the random error.

Five proxy questions were used in constructing the trust index. These were; a. "The buyers/ exporters valued us as their farmers and treated us with care"; b. "There was mutual understanding between us the farmers and the exporters/ buyers"; c. "I believe we were not cheated in terms of the prices we were offered for our organic pineapples"; d. "I will continue supplying the pineapples to the buyer for atleast more than 5 years"; e. "I believe the organic buyer will continue to buy from my fellow organic farmers if I leave the group". The proxy questions were measured on a 3 -point Likert scale measure; $1=$ Strongly disagree $2=$ Neither agree, nor disagree $3=$ Strongly 
disagree

Table 1. Variable description and measurement for the GLM model

\begin{tabular}{|c|c|c|}
\hline Variable & Description & Mean \\
\hline \\
\hline \multirow[t]{3}{*}{ gov } & $\begin{array}{l}\text { Proportion of farmers selling to exporters under the relational } \\
\text { governance }[\mathrm{Gov}=0 \text { (or base) })\end{array}$ & 0.19 \\
\hline & $\begin{array}{l}\text { Proportion of farmers who sold to exporters under the modular } \\
\text { governance }(\mathrm{Gov}=1)\end{array}$ & 0.33 \\
\hline & $\begin{array}{l}\text { Proportion of farmers who sold to exporters under the captive } \\
\text { governance Gov }=2 \text { ) }\end{array}$ & 0.48 \\
\hline \multicolumn{3}{|c|}{ Market/ transaction related variables } \\
\hline Trust & Trust index & 12.51 \\
\hline Contract & Farmer is involved in contract formulation process $1=$ yes $0=$ no & 0.57 \\
\hline Dist & $\begin{array}{l}\text { Number of hours taken to deliver the organic pineapples to the } \\
\text { collection center }\end{array}$ & 1.48 \\
\hline Capt & $\begin{array}{l}\text { Much more capital is required in organic pineapple production than } \\
\text { conventional } 1=\text { strongly disagree } 2=\text { Agree } 3=\text { Strongly agree }\end{array}$ & 2.70 \\
\hline Effort & $\begin{array}{l}\text { Much labor commitment is required in the organic pineapple } \\
\text { production compared to conventional: } 1=\text { strongly disagree } 2=\text { Agree } \\
3=\text { Strongly agree }\end{array}$ & 2.80 \\
\hline Write & $\begin{array}{l}\text { Proportion of farmers that had written contracts }(1=\text { written contract } \\
0=\text { no written contract })\end{array}$ & 0.23 \\
\hline Buy & $\begin{array}{l}\text { Buyers buy less from the farmers than agreed } \\
1=\text { strongly disagree } 2=\text { Agree } 3=\text { Strongly agree }\end{array}$ & 0.57 \\
\hline Pay & $\begin{array}{l}\text { Number of days between the buying of pineapples by the exporters } \\
\text { and when farmers are paid }\end{array}$ & 9.64 \\
\hline \multicolumn{3}{|l|}{ Production variables } \\
\hline Land & Land under organic pineapples (ha) & 0.84 \\
\hline $\operatorname{Exp}$ & Number of years the farmer has grown organic pineapple & 5.84 \\
\hline Train & $\begin{array}{l}\text { Number of times farmer has received training on organic pineapple } \\
\text { production }\end{array}$ & 4.21 \\
\hline \multicolumn{3}{|l|}{ Demographic variables } \\
\hline Age & Age of the farmer (years) & 41.49 \\
\hline$E d u c$ & Education level (years of schooling) of the farmer & 7.07 \\
\hline Sex & $\begin{array}{l}\text { Proportion of farmers who were male }(\text { Male }=1 ; \text { Female }=0) \\
\text { the error term }\end{array}$ & 0.57 \\
\hline
\end{tabular}

\section{Results and Discussion}

\subsection{The Magnitude of the Transaction Costs Experienced by Farmers}

The scores for the transaction costs by farmers in almost all the transaction cost proxies were above two (Table 
2). This shows that transaction costs in organic pineapple value chains are high, considering that the maximum score on the likert scale is 3 (Table 2). Under asset specificity the highest scores were on the labor requirements and capital needed for organic investment compared to the conventional pineapple production. In terms of uncertainty transaction costs, the difficulty in locating other organic buyers in case the contracted organic exporter does not buy the pineapples makes the farmers cautious as they sell to the exporter. Farmers will therefore maintain the conventional market as an alternative market. The high score on the requirement for the written contract (Table 2) also show that farmers are cagey about the reliability of the buyers of organic pineapples. This study found that only $37 \%$ of the farmers had written contracts with the exporters. The lack of written contract may also imply that farmers will maintain the conventional market as a risk minimizing strategy. The possibility that buyers will buy less and the difficulty for buyers to adjust to price changes also imply that the farmers will look for alternative markets.

Table 2. Transaction costs encountered by the farmers under the different governance forms

\begin{tabular}{|c|c|c|}
\hline Transaction cost aspect assessed & The 3 Likert scale measure & Mean score \\
\hline \multicolumn{3}{|l|}{ Asset specificity } \\
\hline $\begin{array}{l}\text { High capital investments than in } \\
\text { conventional pineapple production }\end{array}$ & $\begin{array}{l}1=\text { Less in organic; } 2=\text { No difference; } 3=\text { High in } \\
\text { organic }\end{array}$ & 2.67 \\
\hline $\begin{array}{l}\text { Much commitment of effort and labor in } \\
\text { following organic production rules }\end{array}$ & $\begin{array}{l}1=\text { Less effort in organic; } 2=\text { No difference; } \\
3=\text { More effort in organic }\end{array}$ & 2.50 \\
\hline $\begin{array}{l}\text { Competence to produce as demanded by } \\
\text { buyers }\end{array}$ & $\begin{array}{l}1=\text { High } \quad \text { competence } \quad 2=\text { Indifferent; } 3=\text { No } \\
\text { competence }\end{array}$ & 2.41 \\
\hline $\begin{array}{l}\text { Comparison of management requirements } \\
\text { with conventional pineapple production }\end{array}$ & $\begin{array}{l}1=\text { High } \quad \text { competence } 2=\text { Indifferent; } 3=\text { No } \\
\text { competence }\end{array}$ & 2.81 \\
\hline Average Asset specificity score & & 2.60 \\
\hline \multicolumn{3}{|l|}{ Uncertainty } \\
\hline Need for written contracts & $\begin{array}{l}1=\text { Not important } 2=\text { somehow important; } 3=\text { very } \\
\text { important }\end{array}$ & 2.21 \\
\hline $\begin{array}{l}\text { Effort and time required in contract } \\
\text { formulation }\end{array}$ & $\begin{array}{l}1=\text { Less effort and time } 2=\text { Effort } \& \text { time required } \\
\text { but not a major constraint; } 3=\text { Effort and time } \\
\text { significantly high }\end{array}$ & 2.17 \\
\hline $\begin{array}{l}\text { Difficulty in finding other buyers of organic } \\
\text { pineapples }\end{array}$ & $1=$ Not difficult $2=$ =ndifferent; $3=$ very difficult & 2.47 \\
\hline Difficulty to adjust to quality requirements & $1=$ Not difficult $2=$ =Indifferent; $3=$ very difficult & 1.98 \\
\hline Difficulty to adjust to volume requirements & $1=$ Not difficult $2=$ =ndifferent; $3=$ very difficult & 1.89 \\
\hline Difficulty to adjust to price changes & $1=$ Not difficult $2=$ =ndifferent; $3=$ very difficult & 2.15 \\
\hline Possibility of exporters buying less & $\begin{array}{l}1=\text { Never happens } 2=\text { It can happen; } 3=\text { Often } \\
\text { happens }\end{array}$ & 1.95 \\
\hline Average uncertainty score & & 2.12 \\
\hline
\end{tabular}

The above findings confirm that transaction costs are generally high in high value export agricultural chains (Okello, 2011) although in organic value chains, additional transaction costs arise because of the high capital requirements, difficulty in finding buyers, stricter requirements as compared to conventional value chains. A closer look at the transaction costs (Table 2) shows that scores on asset specificity were higher than scores on uncertainty. The two were, however, strongly correlated $(\mathrm{P}$-value $=0000)$. The strong correlation has been found in other studies, for example, Slater and Spencer (2000) and Kos and Curtis (1997). Macher and Richman (2008) proposed that in empirical analysis, the two should be empirically tested together since one form of transaction property brings about another. Masten (2000) further found that asset specificity leads to uncertainty transaction 
costs and in extreme cases, these transaction costs lead to hold up or no transaction at all (Masten, 2000).

Farmers, on average, mentioned two transaction cost related constraint in organic pineapple production, compared to the single mention of other non-transaction cost production challenges such as pests and diseases. The asset specificity and uncertainty transaction costs which were mentioned by the farmers are summarized in Table 3. The asset specificity transaction costs observed were in various forms that included market specificity, human asset specificity and temporal asset specificity.

Table 3. Summary of transaction costs experienced by the farmers

\begin{tabular}{|c|c|c|}
\hline $\begin{array}{l}\text { Type of transaction } \\
\text { cost }\end{array}$ & Further description of the transaction cost & $\begin{array}{l}\% \text { of farmers that } \\
\text { mentioned the } \\
\text { transaction cost } \\
\text { constraint }\end{array}$ \\
\hline \multicolumn{3}{|l|}{ Farmers } \\
\hline Market specificity & $\begin{array}{l}\text { Small organic consumer market } \\
\text { Prohibition from selling to an alternative organic export company }\end{array}$ & 16.8 \\
\hline $\begin{array}{l}\text { Physical } \\
\text { specificity }\end{array}$ & $\begin{array}{l}\text { Perennial nature of the organic pineapples } \\
2-3 \text { years' conversion period required before a farmer is certified } \\
\text { organic }\end{array}$ & 8.8 \\
\hline Human asset specificity & $\begin{array}{l}\text { Manual weeding } \\
\text { Care in following agronomic, harvest and post-harvest activities }\end{array}$ & 46.0 \\
\hline \multirow[t]{2}{*}{$\begin{array}{l}\text { Temporal } \\
\text { specificity }\end{array}$} & $\begin{array}{l}\text { Highly synchronized harvesting and procurement because of the } \\
\text { perishable nature of pineapples }\end{array}$ & 7.3 \\
\hline & $\begin{array}{l}\text { Unexpected offer of low prices at the time of pineapple } \\
\text { procurement } \\
\text { Constant prices irrespective of changes in prices in the } \\
\text { conventional market }\end{array}$ & 20.4 \\
\hline \multirow[t]{4}{*}{ Uncertainty } & Rejection of part of farmers produce at the time of sale & 0.7 \\
\hline & Uncertainty over when payments would be honored & 9.5 \\
\hline & Exporters buy less of farmers produce & 13.1 \\
\hline & Exporters don't show up & 4.4 \\
\hline
\end{tabular}

Human asset specificity was experienced by almost half of the farmers interviewed (Table 3). Human asset specificity was high because of the extra effort that is needed in weeding the plantations. In organic pineapple farming, weeding is done manually and the sharp serrated leaves makes the exercise difficult. Farmers who used hired labor paid extra money than they would pay if they were producing pineapples conventionally. The quote below by a 50-year-old farmer shows that manual weeding is an important transaction cost in organic farming.

"We encourage farmers to adopt organic farming but they simply laugh at us. Those who spray clear weeds in a matter of hours. Now see my plot, I have been weeding it but it is difficult to manage couch grass. You can see that my hands are all scratched because of the sharp pineapple leaves"

For the farmers that may not stretch the effort required to weed plantations or do not have the capital to hire labor to do the job, the result may be the poorly managed plots and hence a harvest of poor quality pineapples. The poor-quality pineapples may not be accepted in the organic market, and thus be sold to buyers in the conventional market who may not mind much about the quality.

Physical asset specificity occurred because of the limited flexibility in the use of land once it was committed to pineapple production. Organic farmers are required to wait for 1-3 years before they can sell pineapple from a piece of land that has never been certified as organic before (NOGAMU, 2012). In addition, pineapple is a perennial crop which takes 4-6 years in the garden. This implies that in case of contract breach by the buyers, it 
becomes costly for farmers, in terms of lost time and lost opportunities. Whereas Masten (2000) had shown that there is less physical asset specificity in agricultural value chains due to less intricate equipment and skills that are required, this study finds that in organic value chains, the organic production requirements make physical asset specificity high.

Furthermore, temporal asset specificity arose because pineapple is a highly perishable crop, thus requiring highly synchronized harvesting and marketing. Farmers sold the pineapples to the buyers the day they were harvested. This meant that they possibly sold to the conventional market once the pineapples were ready for harvest on the non-scheduled days with the buyers of organic pineapples. In perishable crops, Okello (2011) found that temporal physical asset specificity is inevitable. There was market asset specificity (Table 3) because the market for organic pineapple has specific requirements. For example, the fresh organic pineapple market requires that pineapples are $1.8 \mathrm{~kg}$ or less (Kwikiriza, Mugisha, Kledal, Karantininis \& Namuwooza, 2016). These sizes are mainly obtained when plantations are getting old ( 3 years after establishment). The implication of this is that the bigger sized pineapples are sold to conventional market, thus limiting the amount that can be sold to the organic market. The inability to obtain sufficient quantities of the "right size" pineapples is one of the problems organic consumers in Europe face (CBI, 2008).

Farmers were required to transport the organic pineapples to the collection centers. The bulkiness of the fruits, the sometimes-impassable roads, and the long distances to the centers made the transactions very specific and difficult. In addition, farmers were only permitted to sell to the exporter with whom they had the certification agreement. The quote from one of the group leaders stresses this phenomenon

"My people are in dilemma because the company we supply to is reducing the quantity of pineapples it is buying from us, yet we are not allowed to sell to another organic company that also operates in this village, which incidentally wants more pineapples"

The above phenomenon resulted into farmers selling some of the organic pineapples to local conventional pineapple buyers who bought the pineapples from the farmers' fields. The non- flexibility on the part of the exporters meant that farmers were limited by the contractual obligation to sell part of their produce to the exporters they had contract with.

Other forms of asset specificity included; the requirement for the farmers to harvest at the right stage of maturity, use of a sharp knife to cut the fruits instead of the conventional breaking of the fruit off the stalk, observing maximum hygiene and sorting the pineapples. Following of these criteria potentially reduced the amount the farmers sold to organic market, opting to sell to buyers in the conventional market who were not very particular on some of the aspects that are mandatory in the organic market.

Uncertainty among farmers were a result of their dependence on the exporters as the source of information on production, markets, prices etc. Farmers were at a disadvantage if exporters hid from them essential information necessary during the transactions. For example, about $9 \%$ of the farmers could not tell when they would be paid after selling the fruits (Table 3). In this state of uncertainty, farmers were prompted to sell to buyers in the conventional market who paid promptly. These findings agree with Reeves (2008) and Klein (1996), that uncertainty transaction costs occur because of information asymmetry and the bounded rationality or ignorance of the actors in a transaction.

Uncertainty, such as exporters buying less of farmer's produce, exporters not showing up (Table 3) could also be explained by the seasonal variations in production and the incidence of breaching contracts by either the farmers or the exporters. Figure 1 shows that the proportion of organic pineapples bought from the farmers followed the slump and peak production cycles. The figure shows that the contract price between the farmers and exporters was constant whereas conventional price varied depending on the availability of the pineapples. The shaded area A (Figure 1) denotes the peak harvest periods. In this period, exporters bought a small proportion of the farmers produce because of their lack of capacity to buy all the pineapples produced. This meant that the farmers sold the excess pineapple to the conventional market at a lower price even when the price offered by the exporters was higher. The shaded area B denotes the slump production period. In this period, the price offered by the exporters was lower than what the buyers in the conventional market were willing to offer. In this period, some farmers were motivated to sell to buyers in the conventional market who offered a higher price. Therefore, the transaction costs faced by farmers are season specific, and depend on the nature of the product. This finding agrees with Macher and Richman (2008) and Masten, (2000) that transaction costs are highly dependent on the nature of the product in question. 


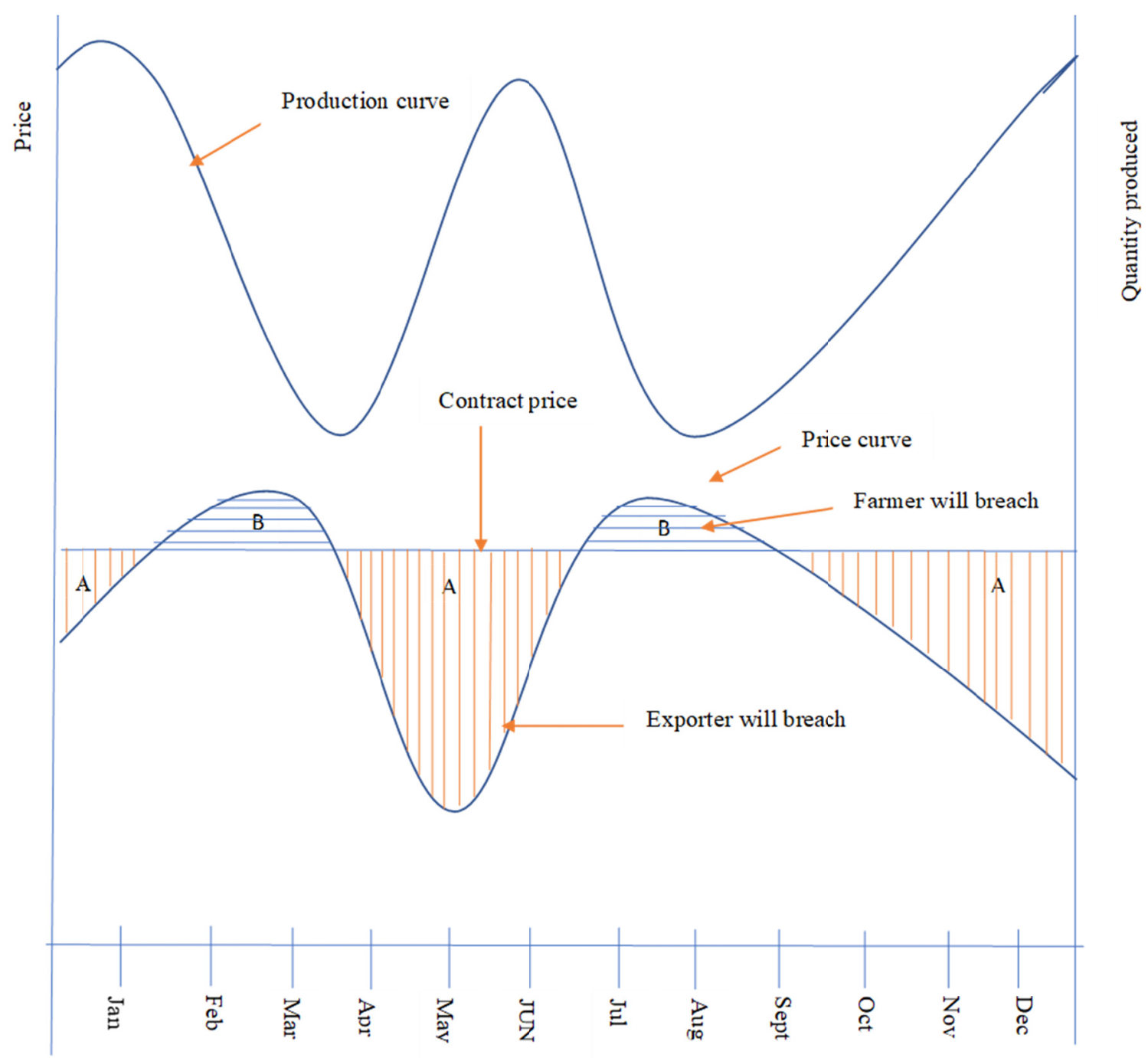

Month of the year

Figure 1. Seasonal variation in production and prices in the organic pineapples from Uganda

Source: own study

\subsection{Transaction Costs Experienced by Exporters}

Exporters, at the establishment stage of their businesses faced several transaction costs. These ex-ante transaction costs include transport costs, telephone calls and time spent in searching and formulating contracts with the farmers. They also faced human asset specific transaction costs which include the trainings and supervision of the farmers to ensure they abide to organic production standards, such as non-use of chemicals, proper harvesting methods and sorting (Table 4). This study established that trainings and supervision of farmers accounted for about $40 \%$ of the export company expenses. 
Table 4. Summary of transaction costs experienced by the exporters

\begin{tabular}{ll}
\hline Type of transaction cost & Further description of the transaction cost \\
\hline Human asset specificity & Training and supervision of farmers \\
Market specificity & Non-sale of pineapples by farmers to other exporters \\
& Delays in the phytosanitary checks \\
& Market search through attending exhibitions \\
Physical asset specificity & Fruit driers meant specifically to dry fruits \\
& Use of special collection vans \\
Uncertainty & Farmers selling organic pineapples to conventional market during periods of \\
& scarcity \\
& Monitoring to ensure organic principles are followed during production \\
\hline
\end{tabular}

Transactions were highly market specific on the part of exporters because of procuring pineapples from farmers they had contracts with. Exporters seldom raised volumes required by the importers, especially in the slump periods (Figure 1). Other market specific transaction costs were delays at airport in doing phytosanitary checks, and expenses in both time and money while attending exhibitions. Through attending both local and international exhibitions, exporters get contacts of buyers/importers and their detailed transaction requirements. Physical asset specificity (Table 4) included the driers and other equipment which were expensive to install but too specific to only drying fruits. Other specific investments were the transportation using specially designed collection vans and crates to avoid bruising of the pineapples.

\subsection{Relationship between Asset Specificity and Uncertainty in Organic Pineapple Value Chains}

Asset specificity and uncertainty were closely associated in bringing about opportunism and hold up in organic pineapple transactions. This is explained in the following illustration. An organic farmer invests in a highly asset specific activity of (a) growing a perennial crop (pineapples) (b) without spraying but involving a lot of manual weeding and (c) for beginners, waiting between 1-3 years of transition before the first sale to the exporter. Farmers make a choice to invest and follow the organic guidelines with a hope of a better and stable market. However, after this high specific investment, the exporter may either (a) fail to turn up to buy (b) purchase less of the agreed quantities or (c) offer lower price. The farmer suffers from the opportunism by the exporter because she/he "cannot read the mind" of the exporter regarding honoring of the contract (bounded rationality). This brings up a hold up on the side of the farmer. The above example also shows that asset specificity proceeds uncertainty and is therefore crucial in determining the magnitude of the transaction costs faced by the actors (Tandelis \& Williamson, 2012). The close relationship between asset specificity and uncertainty implies that reducing one form of transaction cost will lead to the reduction of the other transaction costs.

For the case of exporters, establishing contracts with the farmers, setting up processing industries for organic pineapples and searching for importers is highly market specific. Hold up problems increase for the exporters when farmers sell to the conventional market, especially in the periods of low production when exporters are struggling to meet the demands of the importers. With reduced supply to the importer, the exporter risks losing contract with the importer, as one exporter expressed;

"We invest a lot in these farmers. However, we get disappointed when we ask them pineapples and they keep giving excuses like low production. These farmers are easily convinced by the buyers in the conventional market and they sell the organic pineapples to these people who export to Juba or Nairobi or even in Kampala. The business is frustrating, especially when it is in the slump period".

The above cases show that both farmers and exporters are in search of ways to minimize transaction costs. The farmers will seek options such as maintaining buyers in the conventional market, while exporters make choice of a pineapple product to trade in or will organize farmers in a way to maintain the trade. The next section (4.4) explores how farmers and exporters transacted with each other (governance mechanism) with the aim of minimizing transaction costs in their transaction, although the governances may also bring some specific transaction costs.

\subsection{Governance Forms along the Organic Pineapple Value Chain}

The governance constructs, made after the interviewing exporters and farmers, which were used to distinguish 
the different governance forms in organic pineapple value chains are presented in Table 5. Four types of governance were observed; the modular, captive, relational and spot market. This finding of multiple governance in organic pineapple value chain adds to the evidence (Lee et al., 2010; Dolan \& Humphrey, 2004) that there can be multiple governances in a single chain.

In the modular governance, farmers were organized in cooperatives. Farmers dried the pineapples in their cooperatives before selling to exporters. The exporters trained farmers in their cooperatives and kept in contact with their leaders. The leaders of the cooperatives were engaged in negotiations with the exporters more regularly. Thus, there was easy codification of knowledge during transactions because of knowledge sharing between exporters and cooperative leaders. In this governance, there was increased capability in the supply base because of collective harvesting and delivery to the exporter. Farmers received more trainings and had increased access to loans through other NGOs. The farmers in the cooperative produced other value-added products such as organic wine which they sold in the local organic market. Generally, there was less dependence on the exporters by farmers in the modular governance compared to the other forms of governance.

Table 5. Forms of governance in the organic pineapple value chains

\begin{tabular}{|c|c|c|c|c|}
\hline $\begin{array}{l}\text { Governance } \\
\text { form }\end{array}$ & $\begin{array}{l}\text { Main } \\
\text { distinguishing } \\
\text { characteristic } \\
\end{array}$ & Governance construct & Reason for the construct & $\begin{array}{l}\text { Number } \\
\text { of export } \\
\text { companies }\end{array}$ \\
\hline \multirow[t]{3}{*}{ Modular } & \multirow[t]{3}{*}{$\begin{array}{l}\text { Farmer are } \\
\text { organized in a } \\
\text { cooperative }\end{array}$} & $\begin{array}{l}\text { High ability to codify } \\
\text { transactions }\end{array}$ & $\begin{array}{l}\text { Farmers easily understood the } \\
\text { complexity of the transactions through } \\
\text { their cooperatives }\end{array}$ & \multirow[t]{3}{*}{2 out of 7} \\
\hline & & $\begin{array}{l}\text { High capability } \\
\text { supply base }\end{array}$ & Critical mass of farmers & \\
\hline & & $\begin{array}{l}\text { High complexity } \\
\text { transaction }\end{array}$ & $\begin{array}{l}\text { Selling dry pineapples to exporters } \\
\text { required high level of knowledge, } \\
\text { coordination and ability to follow the } \\
\text { organic principles }\end{array}$ & \\
\hline \multirow[t]{3}{*}{ Relational } & \multirow[t]{3}{*}{$\begin{array}{l}\text { Mainly sold } \\
\text { Fresh } \\
\text { pineapples }\end{array}$} & $\begin{array}{l}\text { Low ability to codify } \\
\text { transactions }\end{array}$ & $\begin{array}{l}\text { Detailed information in producing fresh } \\
\text { pineapple required more trainings from } \\
\text { the exporter }\end{array}$ & \multirow[t]{3}{*}{2 out of 7} \\
\hline & & $\begin{array}{l}\text { High capability } \\
\text { supply base }\end{array}$ & $\begin{array}{l}\text { Procure only small sized pineapples and } \\
\text { hence had less competition from } \\
\text { conventional market }\end{array}$ & \\
\hline & & $\begin{array}{l}\text { High complexity } \\
\text { transaction }\end{array}$ & $\begin{array}{l}\text { Farmers followed strict procedures of } \\
\text { harvesting, weighing and sorting the } \\
\text { pineapples }\end{array}$ & \\
\hline \multirow[t]{3}{*}{ Captive } & \multirow{3}{*}{$\begin{array}{l}\text { Very loose } \\
\text { farmer } \\
\text { groups; sold } \\
\text { for drying }\end{array}$} & $\begin{array}{l}\text { High ability to codify } \\
\text { transactions }\end{array}$ & $\begin{array}{l}\text { Farmers easily produced the final } \\
\text { product as required by the exporter }\end{array}$ & \multirow[t]{3}{*}{3 out of 7} \\
\hline & & $\begin{array}{l}\text { Low capability in supply } \\
\text { base }\end{array}$ & $\begin{array}{l}\text { Very small loose farmer groups, } \\
\text { supplying small quantities }\end{array}$ & \\
\hline & & $\begin{array}{l}\text { High complexity of } \\
\text { transaction }\end{array}$ & $\begin{array}{l}\text { Farmers follow strict organic pineapple } \\
\text { regulations }\end{array}$ & \\
\hline \multirow[t]{3}{*}{$\begin{array}{l}\text { Spot } \\
\text { market }\end{array}$} & \multirow{3}{*}{$\begin{array}{l}\text { Farmers sold } \\
\text { to the } \\
\text { conventional } \\
\text { buyers }\end{array}$} & $\begin{array}{l}\text { High ability to codify } \\
\text { transactions }\end{array}$ & $\begin{array}{l}\text { No strict guidelines in the exchange. } \\
\text { Farmers easily followed the guidelines }\end{array}$ & \multirow{3}{*}{$\begin{array}{l}\text { All the } \\
\text { export } \\
\text { companies }\end{array}$} \\
\hline & & $\begin{array}{l}\text { High capability } \\
\text { supply base }\end{array}$ & $\begin{array}{l}\text { Farmers sold to the conventional market } \\
\text { what buyers of organic pineapples could } \\
\text { not buy }\end{array}$ & \\
\hline & & $\begin{array}{l}\text { Low Complexity } \\
\text { transaction }\end{array}$ & $\begin{array}{l}\text { No specific guidelines followed, } \\
\text { regarding size, quality etc }\end{array}$ & \\
\hline
\end{tabular}

The main distinguishing feature in the relational governance was the export of fresh pineapples (Table 5). This governance required high monitoring by the exporters, since export of fresh pineapples has more stringent rules, for example, sell of small sized fresh pineapples and careful harvesting to avoid bruising. The implication of this was that it was more difficult for this group to codify information. Whereas farmers in the relational governance 
had enough pineapples to supply to the exporters (high supply capacity), each farmer needed to strictly follow several procedures in preparation for export.

The captive governance was characterized by farmers who individually sold fresh pineapples, of any size to the exporters. Exporters dried the pineapples before export. To meet their quantity needs, exporters recruited many farmers. Farmers in this category easily followed the guidelines since they supplied the exporters all fruits they produced and were not involved in any value addition activity before supplying to the exporters.

The modular, relational and captive governances were characteristic of the transactions between the farmers and the organic exporters. However, $61 \%$ of the farmers in addition to selling to the organic market, they sold to the conventional market in a spot market (market governance). These buyers included the exporters especially to South Sudan and Kenya; suppliers in major towns in Uganda, and in the local markets. They maintained this trade to ensure that they can sell their pineapple in case the organic farmers did not buy from them or bought limited quantities.

There were other notable differences in the characteristics and attributes of the farmers under the different forms of governance. Generally, famers in the modular governance were young and had less experience in growing organic pineapples (Table 6). The farmers in this governance also committed small acreages to organic farming. This possibly signify that the modular governance is more inclusive since the exporters deal with the group but not with the individual farmer. The findings also indicate that over $50 \%$ of the farmers in the modular governance were females compared to $35 \%$ in the relational governance. Farmers in the relational governance were more involved in contract formulation and most of these farmers had written contracts (Table 6). This is probably because this governance requires more rules to be followed in the export of the fresh pineapples.

Table 6. Other distinguishing characteristics of the different governance forms

\begin{tabular}{llllll}
\hline Characteristic & \multicolumn{3}{c}{ Nature of governance } & P-value \\
\cline { 2 - 5 } & Relational & Modular & Captive & Overall \\
\hline Age of the farmer & $39.4^{\mathrm{ab}}$ & $37.3^{\mathrm{a}}$ & $43.4^{\mathrm{b}}$ & 40.1 & 0.034 \\
Number of years growing organic pineapple & $9.0^{\mathrm{a}}$ & $4.2^{\mathrm{b}}$ & $5.3^{\mathrm{b}}$ & 5.8 & 0.000 \\
Education (years of schooling) & $7.8^{\mathrm{a}}$ & $8.4^{\mathrm{b}}$ & $6.2^{\mathrm{ab}}$ & 7.4 & 0.012 \\
Proportion (\%) of male farmers & $65^{\mathrm{a}}$ & $49^{\mathrm{a}}$ & $47^{\mathrm{a}}$ & 52 & 0.241 \\
Land (acres) under organic pineapples & $2.3^{\mathrm{a}}$ & $1.3^{\mathrm{a}}$ & $2.4^{\mathrm{a}}$ & 2.0 & 0.083 \\
Involvement of farmer in contract formulation & $79.4^{\mathrm{a}}$ & $49.1^{\mathrm{a}}$ & $50.9^{\mathrm{b}}$ & 57.1 & 0.010 \\
Percent of farmers with written contract & $85.3^{\mathrm{a}}$ & $35.8^{\mathrm{b}}$ & $35.8^{\mathrm{b}}$ & 47.9 & 0.000 \\
Hours taken to reach collection center & $1.1^{\mathrm{a}}$ & $1.7^{\mathrm{a}}$ & $1.5^{\mathrm{a}}$ & 1.5 & 0.504 \\
Trust & $12.6^{\mathrm{a}}$ & $12.7^{\mathrm{a}}$ & $12.3^{\mathrm{a}}$ & 12.6 & 0.581 \\
\hline
\end{tabular}

\subsection{Relationship between Transaction Costs and the Governance Forms}

Transaction costs differed in the different modes of governance, which agrees with the governance theory that Transaction costs give rise to different governances (Gereffi, Humphrey \& Sturgeon, 2005; Tandelis \& Williamson, 2010). Results in Table $7^{1}$ show that in general terms, farmers in the relational governance faced significantly more transaction costs than in captive and the modular governance. In all asset specificity proxy measures, the scores for relational governance were higher. The results also show that the scores for the modular governance were higher than the captive governance, although not significant. The uncertainty scores generally show no significant difference among the governance forms, but it can be observed that the average score for relational is greater than in the captive, and the modular has the lowest score. This result imply that the relational governance has the highest transaction costs than either the captive or the modular governance. 
Table 7. Transaction cost scores in the different forms of governance

\begin{tabular}{|c|c|c|c|c|}
\hline \multirow[b]{2}{*}{ Transaction cost variable } & \multicolumn{4}{|c|}{ Mean scores } \\
\hline & Relational & Modular & Captive & P-value \\
\hline Asset specificity & & & & \\
\hline $\begin{array}{l}\text { High capital investments than conventional pineapple } \\
\text { production }\end{array}$ & $2.88^{\mathrm{a}}$ & $2.69^{\mathrm{a}}$ & $2.61^{\mathrm{a}}$ & 0.120 \\
\hline Difficulty in following organic production rules & $2.50^{\mathrm{a}}$ & $2.50^{\mathrm{ab}}$ & $2.48^{\mathrm{b}}$ & 0.057 \\
\hline Competence to produce as demanded by buyers & $2.75^{\mathrm{a}}$ & $2.35^{\mathrm{b}}$ & $2.34^{\mathrm{b}}$ & 0.014 \\
\hline $\begin{array}{l}\text { Comparison of management requirements with } \\
\text { conventional pineapple production }\end{array}$ & $2.94^{\mathrm{a}}$ & $2.85^{\mathrm{a}}$ & $2.73^{\mathrm{a}}$ & 0.996 \\
\hline Average asset specificity score & $2.77^{\mathrm{a}}$ & $2.60^{\mathrm{b}}$ & $2.54^{\mathrm{b}}$ & 0.003 \\
\hline Uncertainty & & & & \\
\hline Need for written contracts & $2.39^{\mathrm{a}}$ & $2.35^{\mathrm{a}}$ & $2.06^{\mathrm{a}}$ & 0.048 \\
\hline Effort and time in contract formulation & $2.28^{\mathrm{a}}$ & $2.37^{\mathrm{a}}$ & $2.08^{\mathrm{a}}$ & 0.361 \\
\hline Difficulty in finding other buyers of organic pineapples & $2.38^{\mathrm{a}}$ & $1.89^{\mathrm{a}}$ & $2.59^{\mathrm{a}}$ & 0.161 \\
\hline Difficulty to adjust to quality requirements & $1.97^{\mathrm{a}}$ & $1.92^{\mathrm{a}}$ & $2.01^{\mathrm{a}}$ & 0.898 \\
\hline Difficulty to adjust to volume requirements & $1.78^{\mathrm{a}}$ & $2.29^{\mathrm{a}}$ & $1.93^{\mathrm{a}}$ & 0.770 \\
\hline Difficulty to adjust to price changes & $2.36^{\mathrm{a}}$ & $2.29^{\mathrm{a}}$ & $1.97^{\mathrm{b}}$ & 0.022 \\
\hline Possibility of exporters buying less & $2.11^{\mathrm{a}}$ & $1.94^{\mathrm{b}}$ & $2.17^{\mathrm{a}}$ & 0.000 \\
\hline Average uncertainty score & $2.17^{\mathrm{a}}$ & $2.08^{\mathrm{a}}$ & $2.12^{\mathrm{a}}$ & 0.553 \\
\hline
\end{tabular}

$7^{1}$ : Table 7 is an extension of Table 2. The definition and scale measure in this table are like in table 2

Figure 2 illustrates the proportion of farmers that mentioned the different transaction costs as they dealt with the exporters. The figure is based on the number of times a given transaction was mentioned. The figure also shows that generally, there were higher transaction costs in the relational governance. The highest difference is observed in the physical asset specificity, which was mentioned by $68 \%$ of farmers in the relational governance compared to $40 \%$ in the captive and 36 percent in the modular governance. Of interest, also is the buying of fewer pineapples from the harvest in the relational governance. The high proportion of farmers that atleast mentioned a transaction cost ( $85 \%$ for relational, $77 \%$ for modular and $68 \%$ for captive) adds to the evidence observed in the proxy measures (table 7) that farmers in the organic pineapple value chains face high transaction costs. 


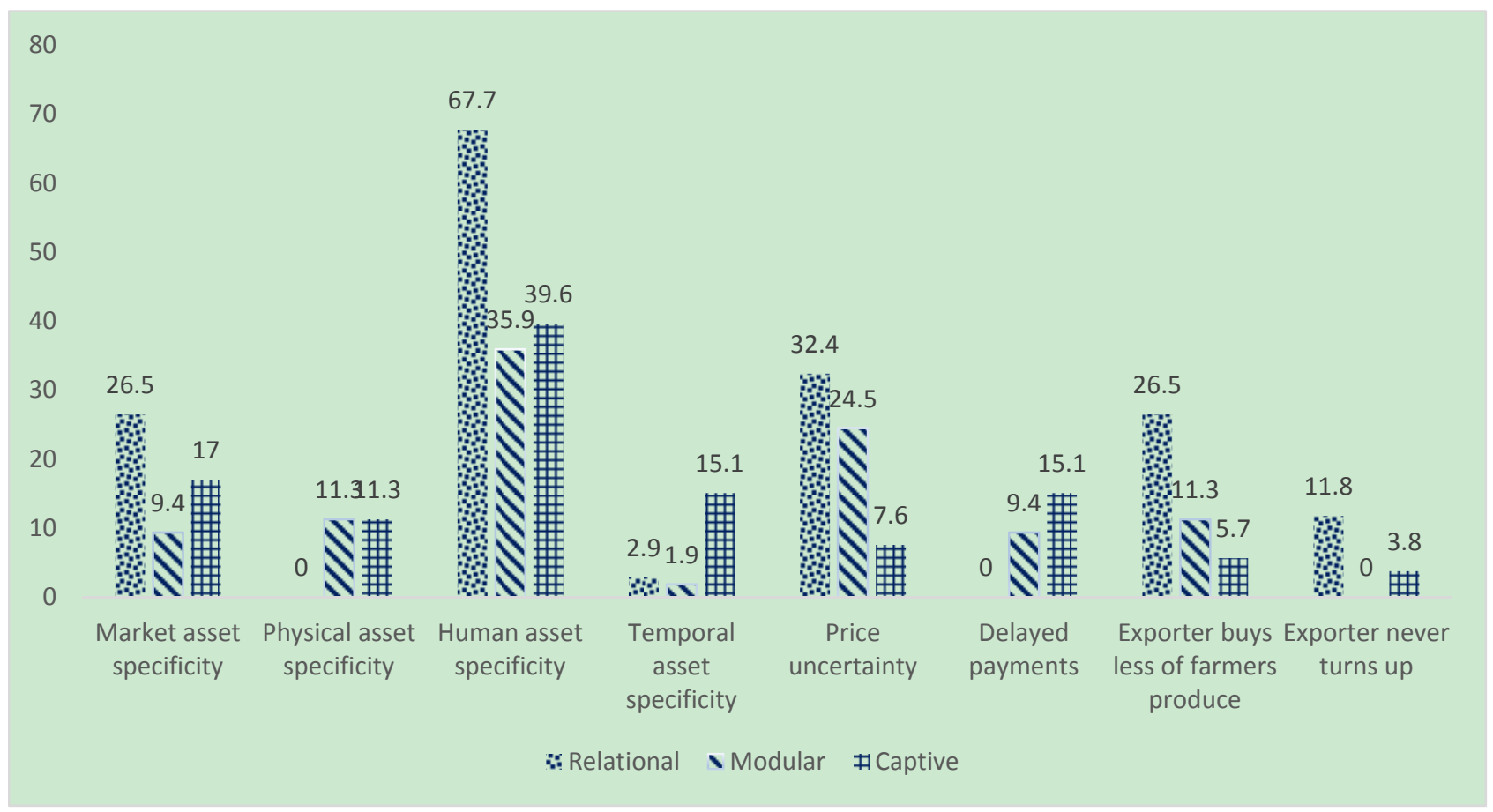

Figure 2. Types of transaction costs incurred by the farmers in the different modes of governance

The differences in transaction costs in the governance forms supports the discriminating alignment hypothesis (Tandelis \& Williamson, 2010) which states that the different transactions are more efficiently governed by different modes of governance. The high transaction costs associated with relational governance than captive governance agrees with Gereffi and Fernandez-Stark (2011) that there are higher transaction costs in relational governance because relational linkages require time to build. Some studies, for example, (Masten, 1984) showed that there were lower transaction costs with the simpler forms of governance (relational, modular) than the complex forms (captive and hierarchy). However, these studies were done on non-agricultural products. The results thus imply that the relationship between the nature of governance and transaction costs depends on the product in question.

The findings on the factors which influence the proportion of organic pineapple exported are presented in Table 8 . Model results indicate that farmers in the modular and captive governance exported a significantly high proportion of pineapples than farmers in the relational governance. Further analysis showed that the proportion of the pineapples exported were $46 \%$ in relational governance, $75 \%$ in modular and $61 \%$ in captive governance. This finding that a small proportion of pineapples is exported in the governance associated with high transaction costs agrees with Salino and Gago de Santos, (2010) that transaction cost impede specification, monitoring and enforcement, and hence the efficiency of any transaction.

Table 8. Factors that influence the proportion of organic pineapples sold to the exporters by the organic pineapple farmers in Uganda

\begin{tabular}{lllll}
\hline Variable & Coeff. & Std. Error & t-value & p-value \\
\hline
\end{tabular}

Dependent variable

proportion of organic pineapples sold to the exporter

Governance forms

Modular; the base is relational governance

Captive; the base is relational governance

Market/ transaction cost related variables

Trust of the farmer to the exporters 
Farmer is involved in contract formulation (1=yes)

$\begin{array}{llll}0.088 & 0.047 & 1.87 & 0.061 \\ 0.020 & 0.011 & 1.82 & 0.069 \\ 0.050 & 0.042 & 1.19 & 0.233 \\ 0.178 & 0.072 & 2.48 & 0.013\end{array}$

Distance to collection center (hours)

Much more capital required in organic pineapple production

production

Requirement for written contracts ( $1=$ yes)

$\begin{array}{llll}-0.057 & 0.050 & -1.13 & 0.257 \\ 0.047 & 0.052 & 0.91 & 0.365 \\ -0.001 & 0.002 & -0.68 & 0.494\end{array}$

Buyers buy less from farmers than agreed

$-0.001$

Production variables

Land under organic pineapples

Experience in pineapple farming (years)

$\begin{array}{llll}0.009 & 0.005 & 1.59 & 0.111 \\ -0.022 & 0.007 & -3.03 & 0.002 \\ 0.004 & 0.005 & 0.77 & 0.444\end{array}$

Organic pineapple training

$-0.002-0.002$

Age of the farmer

$\begin{array}{ll}-0.002 & 0.002\end{array}$

$-1.06$

0.290

Years of formal education

$-0.008 \quad 0.007$

$-1.20$

0.230

Sex of the farmer (1=male)

$-0.119$

0.047

$-2.54$

0.011

Constant

$-0.299 \quad 0.358$

$-0.83$

0.404

$\mathrm{n}=134 ;$ residual $\mathrm{df}=117$; scale parameter $=0.0768$

Model results (Table 8) show that farmers who were involved in the contract formulation process with the exporters exported a high proportion of the pineapples. This study found that $57 \%$ of the farmers were involved in contract formulation with the exporters. The farmers involved in contract formulation sold $73 \%$ of their pineapples to organic market while those who were not involved sold $63 \%$. Farmers pointed that involvement in contract formulation gives them confidence that the important contract terms such as assurance that the buyers will turn up, regular payment will be adhered to. Interestingly, this study found that having a written contract did not significantly influence the proportion of pineapples sold. Previous studies have shown that written contracts mitigate transaction hazards (Tirole, 2007; Anderson, 2005) and compensate for investment in high specific assets (Tandelis \& Williamson, 2010). This study has however revealed that involvement of farmers in contract formulation is more important than having the written contracts in which farmers have not been involved. It therefore pays off for the exporters to engage famers in contract formulation so that they can buy more pineapples from them.

Results show a positive and significant relationship between the proportion of the organic pineapples sold and the distance from the farm to the point of sale. This finding is contrary to what was expected. Many studies on agricultural products (Tufa, Bekele \& Zamedu, 2014; Onoja, Usoroh, Adieme \& Deedam, 2012; Alene et al., 2008) have consistently found a significant and negative relationship between distance and amount of the product sold. Only $19 \%$ of the farmers sold at farmgate and those that sold off farm, on average took one and half hours to reach the collection centers. Further analysis indicates that farmers who mentioned market specific transaction costs, in which distance to the collection center is categorized, sold $67 \%$ of the organic pineapples to the organic market compared to the average $62 \%$ of the whole sample. The positive relationship between distance and proportion of farmer sales to organic buyers could be explained by the lack of alternative markets for the farmers who were far away from the organic pineapple bulking centers. Some export companies also recruited farmers in localities that are not easily accessible to avoid competition from buyers of conventional pineapples. Price offers by the conventional market in such areas are also very low and therefore, farmers are better off walking the far distances to sell their pineapples to the buyers of organic pineapples. This finding imply that organic market provides a better marketing option for farmers that are far away from access amenities.

Farmers that perceived that organic pineapples require more effort in terms of time and labor in management had a significantly high proportion of organic pineapples sold to buyers of organic pineapples. This is possibly because farmers commit the time and labor after they have already made decisions to sell to the organic market. The farmer will therefore sell as much pineapple as possible to the organic market which offers premium prices to compensate for the high investment in terms of labor. This finding imply that the asset specific transaction 
costs possibly affect the future decisions of the farmers on whether to continue producing for the organic market or to shift to the conventional market than the current decisions on selling a small proportion to the organic market. Studies Tilore, (2007) and Joskow (1987) both indicate that high asset specific investments require longer term investments for repeated transactions rather than repeated bargaining. It therefore implies that in the organic pineapple value chains, once farmers commit to selling to the organic buyer, the farmer will incur losses if they sold much of the produce to conventional market.

Trust increased the proportion of the organic pineapples sold. Trust makes the farmers to believe the buyers that they will not be cheated, they will be paid in time and that their pineapple will be bought. In organic value chains, trust is important in giving property rights to access and inclusion. Dyer and Chu, (2003) show that trust reduces transaction costs and improves value chain performance.

A few other exogenous variables influenced the amount of organic pineapple exported (Table 8). Female farmers sold a large proportion of their pineapple to the organic exporters compared to the male farmers. Female farmers explained that they preferred selling to buyers of organic pineapples because they were more reliable. In addition, they argued that they were less mobile in the effort to search for other conventional buyers compared to their male counterparts. This finding is important because it shows that females can engage and benefit from high value cash crops, despite that in developing countries, most cash crops are managed by men (Peterman, Quisumbing, Behrman \& Nkonya, 2011). Farmers' experience in organic pineapple growing had a significant and negative relationship with the proportion sold to the exporters. Lawless, (2013) found experience to be positively related to amount exported. In this study, farmers had averagely 5.4 years in organic pineapple farming. Farmers who had managed pineapples in less than 5 years sold $69 \%$ of their pineapples to the exporters compared to $55 \%$ sold to exporters by those who had more than 5 years of experience. Further analysis shows that farmers with more experience mentioned significantly more transaction costs than those who had less experience (P-value 0.002). The cumulative transaction costs by farmers with more experience possibly discourage them from selling to exporters and will thus seek other buyers. Experience also gives the farmers an opportunity to interact and eventually sell to many conventional buyers.

\section{Conclusions and Recommendations}

The study explored the transaction costs faced by both farmers and exporters. This study has established that there are high transaction costs faced by both exporters and farmers which limit the proportion of the pineapples exported. Important transaction costs incurred by farmers include high effort requirements, high capital investment, failure of the buyers turning up to buy the pineapples and unreliable payments. The organic pineapple value chain is characterized by multiple governances and the organic pineapple specific governances are the modular, captive and relational governance. The study also concludes that the governance that is associated with the highest transaction costs has the least proportion of pineapples sold through it by the farmers. However, the influence of transaction costs on the proportion sold by the farmers is case by case specific. Specifically, farmers who incur high asset specific transaction costs for example, farmers far away from collection centers, farmers that consider organic farming requiring more effort compared to conventional farming will sell high proportion of their pineapples to the exporters. Policy measures that could lead to a high proportion of organic pineapples sold to the organic market are; supporting export companies to process and export various pineapple products including fresh pineapple, pulp and dried pineapple so that all pineapples are bought irrespective of size. Government and support institutions should explore establishing domestic organic markets so that the farmers are well cushioned in case the exporters cannot buy all their pineapples.

The study also concludes that it pays off if exporters involve farmers in contract formulation rather than handing them written contracts in which they were not involved in their formulation. As such, support institutions such as NOGAMU should work closely with exporters to ensure that they involve farmers whenever new contracts are to be made. Hedging against uncertainty through trust building positively influences the proportion of organic pineapples farmers sell to the exporters. As a policy recommendation, exporters should invest in building trust through establishing long term contracts with the farmers, frequent visits to the farmers and adhering to the contract terms.

The modular governance had other positive attributes for smallholder involvement in addition to having relatively fewer transaction costs compared to the relational and captive governance. For example, the farmers had smallest acreages, they were young and with less experience and yet this category of farmers sold higher proportion of pineapples to exporters. The modular governance should thus be promoted. Since the modular governance is characterized by farmers organized in cooperatives and engaging in value addition, the government agricultural extension agents, NGOs that support organic farmers at both national and local level 
should promote cooperatives among the organic pineapple farmers.

\section{Acknowledgements}

We are grateful for the funding through Productivity for Growth of Organic Value Chains (ProGroV) for funding this study. We acknowledge the farmers and exporters who gave their valuable time to participate in the study.

\section{References}

Agro Eco, B. V., \& Grolink, A. B. (2008). Organic exports - A way to a better life? Retrieved September 28, 2015, from http://www.grolink.se/epopa/Publications/Epopa-endbook.pdf

Alene, A. D., Manyong, V. M., Omanya, G., Mignouna, H. D., Bokanga, M., \& Odhiambo, G. (2008). Smallholder market participation under transactions costs: Maize supply and fertilizer demand in Kenya. Food policy, 33(4), 318-328.

Bar-Hillel, M. (1979). The role of sample size in sample evaluation. Organizational Behavior and Human Performance, 24(2), 245-257. http://dx.doi.org/10.1016/0030-5073(79)90028-X

Benham, A., \& Benham, L. (2001). The costs of exchange. 2000): Institutions, Contracts and Organizations: Perspectives from New Institutional Economics, Edward Elgar, Cheltenham, pp.367-375.

CBI. (2008). CBI market Survey: The EU market for pineapples. Retrieved from $\mathrm{http}: / /$ www.cadexco.bo/actual/boletin-inteligencia/Pineapple\%20Survey.pdf

Dolan, C., \& Humphrey, J. (2004). Changing governance patterns in the trade of flesh vegetables between Africa and the United Kingdom. Environmental and planning, 36, 491-509.

Dyer, H, J., \& Chu, W. (2003). The role of trustworthiness in reducing transaction costs and improving performance. Empirical evidence from the United states, Japan and Korea. Jstor, 14(1), 57-68.

Gereffi, G., \& Karina Fernandez-Stark, K. (2011). Global value chain analysis: A primer.

Gereffi, G., Humphrey, J., \& Sturgeon, T. (2005). The governance of global value chains. Review of International Political Economy, 12(1), 78-104.

Gibbon, P., \& Bolwig, S. (2007). The economic impact of a ban on imports of air freighted organic products to the UK, DIIS Working Paper No. 2007: 23.

Gibbon, P., \& Ponte, S. (2008). Global value chains: from governance to governmentality? Economy and Society, 37(3), 365-392. Retrieved from https://www.tandfonline.com/doi/abs/10.1080/03085140802172680

González-Moralejo, S. A., Muñoz, P. M., \& Miquel, J. F. L. (2015). Firm Size, Contractual Problems and Organizational Decision-Making: Logistics for Perishable Goods. International Food and Agribusiness Management Review, 18(4), 89.

Halldórsson, A., Tage, S., \& Herbert, K. (2003). Inter-organizational Theories behind Supply Chain Management. - Discussion and Applications, pp.31-46

IFOAM. (2002). http://www.ifoam.bio/sites/default/files/page/files/ifoam_annual_report_2002.pdf

Joskow, P. (1987). Contract duration and relation-specific investments: Empirical evidence from coal markets. American Economic Review, 77(1), 168-185.

Kilcher, L., Willer, H., Huber, B., Frieden, C., Schmutz, R., \& Schmid, O. (2011). The Organic market in Europe. Overview and market access information for producers and international trading companies. Fourteen country examples in the European free trade association and the European Union, with a special focus on Switzerland. FiBL and Sippo, Frick and Zürich. Retrieved September 22, 2015, from http://orgprints.org/18347/

Koss, P. A., \& Curtis, B. E. (1997). Co-specific investments, hold-up and self-enforcing contracts. Journal of Economic Behavior and Organization, 32, 457-470.

Kwikiriza, N., Mugisha, J., Kledal, P, R., Karantininis, K., \& Namuwooza, C. (2016). Tracing Uganda's global primary organic pineapple value chain. African Crop Science Journal, 24(1), 1-11.

Lawless, M. (2013). Marginal distance: Does export experience reduce firm trade costs?. Open economies review, 24(5).

Lee, J. (2010). Global commodity chains and global value chains. In R. A. Denemark (Ed.), The International studies Encyclopedia (pp.2987-3006). Oxford:Wiley-Blackwell. 
Macher, J. T., \& Richman, B. D. (2008). Transaction cost economics: An assessment of empirical research in the social sciences. Business and Politics, 10(1).

Martinez, S. W. (2002). Vertical coordination of marketing systems: Lessons from the poultry, egg, and pork industries. BiblioGov.

Masten, S. E. (1984). The organization of production: Evidence from the aerospace industry. The Journal of law and economics, 27(2), 403-417.

Masten, S. E. (2000). Transaction-cost economics and the organization of agricultural transactions. In Industrial organizations (pp. 173-195). Emerald Group Publishing Limited.

Masten, S. E., \& Saussier, S. (2000). Econometrics of contracts: An assessment of developments in the empirical literature on contracting. Revue d'Economie industrielle, 92(1), 215-236.

Masten, S. E., \& Saussier, S. (2002). Econometrics of Contracts: An assessment of developments in the empirical literature of Contracting. In Brousseau E., \& Glachant J.-M. (Eds.), the Economics of Contracts: Theories and Applications. Cambridge University Press.

Neish, I. (2008). Structure and Development of Tropical Red Seaweed Value Chains with Focus on the Red Algal Galactan Seaplants (RAGS). SEAPlant.net Monograph No. HB2A 0808 V1.

NOGAMU. (2012). Certified Organic Companies in Uganda. Retrieved September 28, 2015, from $\mathrm{http}: / /$ www.nogamu.org/cope_members.php

North, D. C. (1990). Institutions, institutional change and economic performance. Cambridge university press.

Okello, J. J. (2011). Exit, voice and loyalty in Kenya's French bean industry: what lessons can we learn from smallholder farmers' past response to international food safety standards? African Journal of food agriculture nutrition and development, 11(1).

Onoja, O. A., Usoroh, B. B., Adieme, D. T., \& Deedam, N. J. (2012). Determinants of market participation in Nigerian small-scale fishery sector: Evidence from Niger delta region. The journal of sustainable Development, 9(1), 69-84. https://doi.org/10.7916/D85M65FZ

Papke, L. E., \& Wooldridge, J. M. (1996). Econometric methods for fractional response variables with an application to 401(K) plan participation rates. Journal of Applied Econometrics, 11, 619-632.

Peterman, A., Quisumbing, A., Behrman, J., \& Nkonya, E. (2011). Understanding the complexities surrounding gender differences in agricultural productivity in Nigeria and Uganda. Journal of Development Studies, 47(10), 1482-1509.

Ponte, S., Kelling, I., Jespersen, K. S., \& Kruijssen, F. (2014). The blue revolution in Asia: upgrading and governance in aquaculture value chains. World Development, 64, 52-64.

Reeves, E. (2008). The practice of contracting in public private partnerships: transaction costs and relational contracting in the Irish schools sector. Public Administration, 86(4), 969-986.

Singh, P. K. I., Kumar, V., Singh, S., Singh, M., \& Shukla, V. K. (2009). Growth and yield pattern of mustard crop during conversion from conventional to organic farming. In, Bioacademy 2009. Proceedings of the $2^{\text {nd }}$ scientific conference. Organic farming-a response to economic and environmental challenges. IFOAM, EU GROUP.

Slater, G., \& Spencer, D. A. (2000). The uncertain foundations of transaction costs economics. Journal of Economic Issues, 34(1), 61-87.

Soliño, A. S., \& Gago de Santos, P. (2010). Transaction costs in transport public-private partnerships: comparing procurement procedures. Transport Reviews, 30(3), 389-406.

Tadelis, S., \& Williamson, O. E. (2012). Transaction cost economics. University of California, Berkeley, 14.

Tufa, A., Bekele, A., \& Zemedu, L. (2014). Determinants of smallholder commercialization of horticultural crops in Gemechis District, West Hararghe Zone, Ethiopia. African journal of agricultural research, 9(3), 310-319.

UIA. (2008). Uganda Investment Authority. Small and Medium enterprises (SME) Business Guide. Kampala, Uganda. Retrieved from ww.iceida.is/media/pdf/SME_GUIDE_FINAL_COPY.pdf

Williamson, O. (2005). Transaction cost economics. Handbook of new institutional economics, pp.41-65.

Williamson, O. E. (1975). Markets and hierarchies: analysis and antitrust implications - A study in the 
Economics of internal organization. Free Press, New York.

Williamson, O. E. (1985). The Economic Institutions of Capitalism. Free Press, New York.

\section{Copyrights}

Copyright for this article is retained by the author(s), with first publication rights granted to the journal.

This is an open-access article distributed under the terms and conditions of the Creative Commons Attribution license (http://creativecommons.org/licenses/by/4.0/). 